\title{
Misconceptions of pathophysiology of happy hypoxemia and implications for management of COVID-19
}

\author{
Martin J. Tobin*, Amal Jubran and Franco Laghi
}

\begin{abstract}
In the article "The pathophysiology of 'happy' hypoxemia in COVID-19," Dhont et al. (Respir Res 21:198, 2020) discuss pathophysiological mechanisms that may be responsible for the absence of dyspnea in patients with COVID-19 who exhibit severe hypoxemia. The authors review well-known mechanisms that contribute to development of hypoxemia in patients with pneumonia, but are less clear as to why patients should be free of respiratory discomfort despite arterial oxygen levels commonly regarded as life threatening. The authors propose a number of therapeutic measures for patients with COVID-19 and happy hypoxemia; we believe readers should be alerted to problems with the authors' interpretations and recommendations.
\end{abstract}

\section{Letter}

We read with interest "The pathophysiology of 'happy' hypoxemia in COVID-19" by Dhont et al. [1]. We agree with many of their points but disagree on several important facets.

Dhont and colleagues [1] claim that increases in respiratory rate and tidal volume are "the most important clinical signs of impending hypoxemic respiratory failure." On the contrary, neither rate nor tidal volume are sensitive or specific for hypoxemia. The essential point about happy hypoxemia is that patients can be profoundly hypoxic and yet exhibit no abnormality in breathing pattern [2].

Dhont et al. [1] claim that a leftward shift in the oxyhemoglobin-dissociation curve explains "why $\mathrm{SpO}_{2}$ can be well-preserved in the face of a profoundly low $\mathrm{PaO}_{2}$." Given that the carotid bodies respond solely to arterial oxygen tension $\left(\mathrm{PaO}_{2}\right)$, and not to arterial oxygen saturation $\left(\mathrm{SaO}_{2}\right)$ [1], a leftward shift of the

\footnotetext{
* Correspondence: mtobin2@lumc.edu

Division of Pulmonary and Critical Care Medicine, Hines Veterans Affairs Hospital and Loyola University of Chicago Stritch School of Medicine, Hines, IL 60141, USA
}

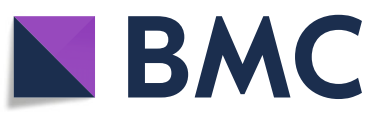

(C) The Author(s). 2020 Open Access This article is licensed under a Creative Commons Attribution 4.0 International License, which permits use, sharing, adaptation, distribution and reproduction in any medium or format, as long as you give appropriate credit to the original author(s) and the source, provide a link to the Creative Commons licence, and indicate if changes were made. The images or other third party material in this article are included in the article's Creative Commons licence, unless indicated otherwise in a credit line to the material. If material is not included in the article's Creative Commons licence and your intended use is not permitted by statutory regulation or exceeds the permitted use, you will need to obtain permission directly from the copyright holder. To view a copy of this licence, visit http://creativecommons.org/licenses/by/4.0/ The Creative Commons Public Domain Dedication waiver (http://creativecommons.org/publicdomain/zero/1.0/) applies to the data made available in this article, unless otherwise stated in a credit line to the data.

dissociation curve would increase the likelihood of dyspnea-the opposite of happy hypoxemia.

Diagnosis of happy hypoxemia in COVID-19 is typically prompted by low pulse oximeter readings. Pulse oximetry markedly exaggerates the severity of low oxygen saturations when readings are low [2] (and this will not enhance carotid-body stimulation). Additionally, fever (a frequent occurrence in COVID-19) moves the oxygendissociation curve to the right. For example, a temperature of $40^{\circ} \mathrm{C}$ will produce a decrease in oxygen saturation of $9.9 \%$ without change in $\mathrm{PaO}_{2}$ [2]. This substantial desaturation will not increase carotid-body stimulation-a perfect set-up for happy hypoxemia.

Dhont and colleagues [1] claim that increases in negative inspiratory intrathoracic pressure in COVID-19 patients will produce patient self-inflicted lung injury ( $\mathrm{P}$ SILI). There is no evidence that P-SILI occurs in patients with COVID-19 [3]. Indeed, there is no direct experimental proof for the occurrence of P-SILI in human subjects [4].

Dhont et al. [1] invoke involvement of pulmonary vasculature and intravascular microthrombi in COVID-19. There is, however, no known physiological mechanism 
whereby such involvement can cause suppression of dyspnea-the clinical hallmark of happy hypoxemia [2].

Dhont and colleagues [1] claim that reduction of cytokine storm is a major therapeutic goal in COVID-19. Where are the data to indicate that specific measures ameliorate cytokine storm and where is the evidence that measures directed at such a target will benefit patients?

The authors list a series of therapies-including tissue plasminogen activator (tPA), anti-inflammatory agents (tocilizumab, sarilumab, siltuximab), and modulators of the renin-angiotensin system-for use in COVID-19 patients. Each agent carries major potential for patient harm, and there is no conceivable mechanistic pathway whereby they will reverse the absence of dyspnea in hypoxemic COVID-19 patients (happy hypoxemia) [2].

Dhont and colleagues [1] claim that intubation and invasive ventilation is advantageous over non-invasive ventilation through decreases in oxygen debt, by avoidance of P-SILI, and by offering a better chance for the lungs to heal. No form of ventilator support is motivated by concerns about oxygen debt [5]. There is no proof that P-SILI occurs in COVID-19 patients [3, 4]. No form of ventilator support has been shown to increase lung healing [5].

Dhont et al. [1] claim that most severely ill COVID-19 patients fulfil the Berlin criteria of ARDS, and on this basis judge certain aspects of mechanical ventilation as "key" steps. Problems that ensue from such a mindset is highlighted by data contained in a report from a NIH-ARDS Network center, which involved 66 patients with COVID-19 (85\% with ARDS) who were "managed with mechanical ventilation and established ARDS protocols" [6].

Analyzing these data, Yaroshetskiy et al. [7] point out that the patients had relatively high $\mathrm{PaO}_{2} / \mathrm{FiO}_{2}$ (median 245 [equivalent to $\mathrm{PaO}_{2} 98 \mathrm{mmHg}$ with fractional inspired oxygen concentration, $\mathrm{FiO}_{2}$, of $40 \%$, and $\mathrm{PaO}_{2} /$ $\mathrm{FiO}_{2} 320-560$ in many); plateau pressure of only 21 $\mathrm{cmH}_{2} \mathrm{O}$; driving pressure of only $11 \mathrm{cmH}_{2} \mathrm{O}$; positive end-expiratory pressure (PEEP) higher when prone than when supine; administration of paralytic agents in $42 \%$; and administration of vasopressors in 95\% [6]. Based on the reported physiological variables, Yaroshetskiy et al. [7] ask a rhetorical question "Do all these patients definitely require intubation and mechanical ventilation?"

For the clinician at the bedside of a COVID-19 patient, the only consequent of making a diagnosis of ARDS is avoidance of tidal volume $12 \mathrm{ml} / \mathrm{kg}$. Given that tidal volume $12 \mathrm{ml} / \mathrm{kg}$ is not employed in any patient, making a diagnosis of ARDS does not impact selection of any ventilator setting in COVID-19 [8].

We are concerned that Dhont and colleagues [1] link the phenomenon of happy hypoxemia to drastic therapies of unproven benefit and such therapies are more likely to be harmful than hypoxemia-which frequently responds to much simpler measures [9].

\section{Abbreviations}

COVID-19: Coronavirus Disease 2019; $\mathrm{PaO}_{2}$ : Arterial oxygen tension; $\mathrm{SaO}_{2}$ : Arterial oxygen saturation; P-SILI: Patient self-induced lung injury; tPA: Tissue plasminogen activator; ARDS: Acute respiratory distress syndrome: $\mathrm{NIH}$ : National Institute of Health; $\mathrm{FiO}_{2}$ : Fractional inspired oxygen concentration; PEEP: Positive end-expiratory pressure

\section{Acknowledgements}

Not applicable.

Authors' contributions

MT, AJ and FL contributed to writing the manuscript. All authors read and approved the final manuscript.

\section{Funding}

National Institute of Nursing Research (R01-NR016055) and Merit Review Award, Veterans Administration Research (1 101 RX002803-01A1).

Availability of data and materials

Not applicable.

Ethics approval and consent to participate

Not applicable.

\section{Consent for publication}

Not applicable.

\section{Competing interests}

MJT receives royalties for two books on critical care published by McGrawHill, Inc., New York.

Received: 23 August 2020 Accepted: 22 September 2020

Published online: 24 September 2020

References

1. Dhont S, Derom E, Van Braeckel E, Depuydt P, Lambrecht BN. The pathophysiology of 'happy' hypoxemia in COVID-19. Respir Res. 2020;21:198. https://doi.org/10.1186/s12931-020-01462-5.

2. Tobin MJ, Laghi F, Jubran A. Why COVID-19 silent hypoxemia is baffling to physicians. Am J Respir Crit Care Med. 2020;202(3):356-60.

3. Tobin MJ, Laghi F, Jubran A. Caution about early intubation and mechanical ventilation in COVID-19. Ann Intensive Care. 2020;10(1):78.

4. Tobin MJ, Laghi F, Jubran A. P-SILI is not justification for intubation of COVID-19 patients. Ann Intensive Care. 2020:10(1):105.

5. Laghi F, Tobin MJ. Indications for mechanical ventilation. In: Tobin MJ, editor. Principles and practice of mechanical ventilation. 3rd ed. New York: McGraw-Hill, Inc.; 2013. p. 101-35.

6. Ziehr DR, Alladina J, Petri CR, Maley JH, Moskowitz A, Medoff BD, et al. Respiratory pathophysiology of mechanically ventilated patients with COVID-19: a cohort study. Am J Respir Crit Care Med. 2020;201(12):1560-4.

7. Yaroshetskiy Al, Avdeev SN, Konanykhin VD. ARDS in COVID-19: do all these patients definitely require intubation and mechanical ventilation? Am J Respir Crit Care Med. 2020. https://doi.org/10.1164/rccm.202007-2713LE.

8. Tobin MJ. Does making a diagnosis of ARDS in patients with COVID-19 matter? Chest. 2020. https://doi.org/10.1016/j.chest.2020.07.028.

9. Tobin MJ. Basing respiratory management of COVID-19 on physiological principles. Am J Respir Crit Care Med. 2020;201(11):1319-20.

\section{Publisher's Note}

Springer Nature remains neutral with regard to jurisdictional claims in published maps and institutional affiliations. 